\title{
Evidence for a decline of François' langur Trachypithecus francoisi in Fusui Nature Reserve, south-west Guangxi, China
}

\author{
Gang Hu, Xin Dong, Yi Wei, Ying Zhu and Xihuan Duan
}

\begin{abstract}
Between July 2000 and June 2001 we undertook a survey of François' langur Trachypithecus francoisi and its habitat in the Fusui Nature Reserve in south-west Guangxi, China, where 86 individual langurs were recorded in 1995. In our first survey period we located 45 individuals in 10 groups, but c. 12 months later, despite expending more effort, we were only able to locate three of the 10 groups, totalling 23 individuals. In all, in three separate surveys, we recorded densities that were $26-52 \%$ of the 1995 figures. Within the Reserve almost all of the valley bottoms and most flat areas in the hills have been cultivated and there is steady encroachment into the hills and forests. The majority of
\end{abstract}

local families depend on the forest for firewood. It appears that habitat loss and illegal hunting are responsible for the decline of François' langur. We recommend that alternative income generating activities and energy sources should be explored to reduce human pressure on these langurs and their habitat. More funding should also be made available to the Reserve to enable staff to adequately tackle issues of hunting and habitat destruction.

Keywords China, François' langur, Fusui Nature Reserve, Guangxi, population decline, Trachypithecus francoisi.

\section{Introduction}

François' langur Trachypithecus francoisi is an Endangered species (IUCN, 2002) found in the forests of southern China and the border area with India and Vietnam. Several closely related species (Hatinh langur T. hatinhensis, Laotian langur T. laotum, Delacour's langur $T$. delacouri and white-headed langur T. francoisi leucocephalus) are found south of the Red River in northernmost Vietnam (Fooden, 1976; Groves, 2001). In southern China, François' langur was historically recorded from 23 counties in Guangxi Province and nine counties in Guizhou Province (Fig. 1) at altitudes of 120-1,400 m (Li \& Ma, 1980; Ma \& Wang, 1988; Ma et al., 1989; Zhang et al., 1992; Li, 1993). François' langur is threatened by habitat destruction and fragmentation, and poaching (Wang et al., 1999). Since the 1980s François' langur has been listed as a Category I Species, the highest level of

Gang Hu (Corresponding author) and Xin Dong Institute of Wildlife, Southwest Forestry University, Kunming, Yunnan 650224, China. Email hgiwswfc@public.km.yn.cn

Yi Wei Wildlife \& Natural Reserve Management Station, Guangxi Forestry Department, Qixin Road, Nanning, Guangxi 530022, China.

Ying Zhu Gaoligongshan National Reserve Management Bureau, Gongyuan Road, Baoshan, Yunnan 678000, China.

Xihuan Duan Wuliangshan National Reserve Management Bureau, Nanjian County, Yunnan 675700, China.

Received 5 December 2001. Revision requested 13 May 2002. Accepted 7 March 2003. protection, under the Wild Animal Protection Law in China.

Since 1955 there has been debate over the taxonomy of the François' and white-headed langurs. The whiteheaded langur was originally described by Tan (1955) as a new species of the genus Presbytis. Some authors have since suggested that the white-headed langur is a separate species in the genus Trachypithecus (T. leucocephalus; Eudey, 1987; Lu \& Li, 1991), while others have considered it a subspecies of François' langur (T. francoisi leucocephalus; Li \& Ma, 1980; Liu et al., 1997; Wang et al., 1997; Ding et al., 1999; Wang et al., 1999; Groves, 2001). In China, most recent ecological studies have concentrated on the white-headed langur (Li, 1993; Lu \& Huang, 1993; Hu et al., 1998, 1999; Huang et al., 1995, 1998, 2000, 2001, 2002). In contrast less is known of the distribution, status and ecology of François' langurs (Li \& Ma,1980; Huang et al., 1983; Ma et al., 1989; Bennett \& Davies, 1994; Yang, 1994; Li, 1995; Liu \& Wei, 1995; Wang et al., 1999; Luo et al., 2000; Zhou et al., 2001). Although poaching has been banned since the 1980s, habitat destruction in the François' langur's habitat has increased in recent years, and this threatens the survival of the species. Effective conservation action based on a full understanding of the species' current status is needed.

The aims of this study were to assess the status of François' langur in an important protected area for the species, Fusui Nature Reserve, to examine the socioeconomic status of local human communities (because this may have a bearing on the conservation of the langur), 

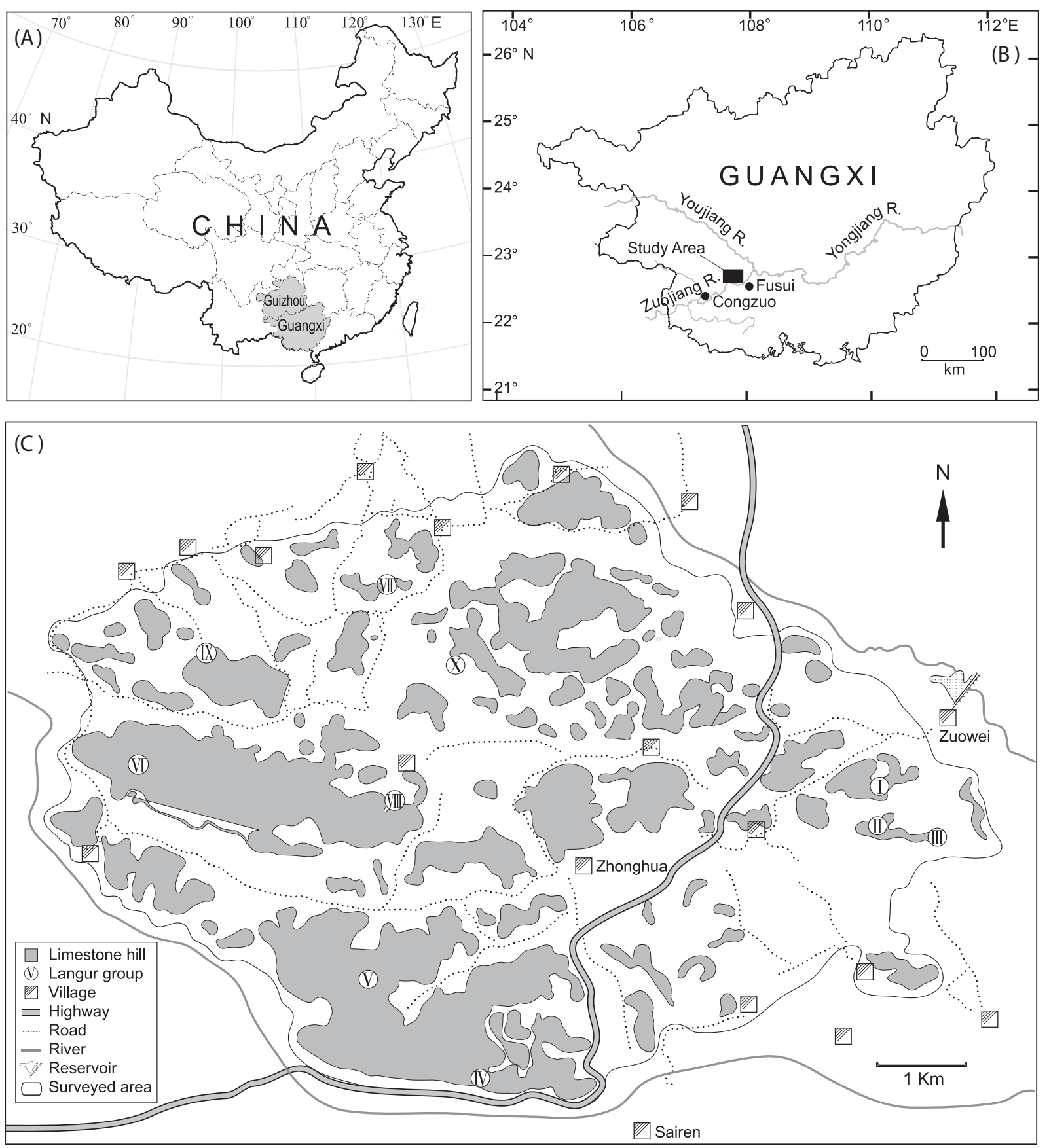

Fig. 1 (A) The historical range of François' langur in China (Guangxi and Guizhou Provinces). (B) The location of the surveyed area in Guangxi Province. (C) The surveyed area, with the limestone hills, locations of the 10 langur groups (I-X), and rivers, reservoirs, villages and roads.

and to provide management recommendations for local conservation agencies.

\section{Study area}

The $80 \mathrm{~km}^{2}$ Fusui Nature Reserve is in south-west Guangxi, China (Guangxi Forestry Department, 1993) near the Vietnamese border (Fig. 1). The Zuojiang River divides the reserve into two parts, and François' langurs occur only in the northern area, in the townships of Zhonghua and Sairen. White-headed langurs occur only south of the river. The area is dominated by a karst landscape of limestone hills with steep cliffs, sinkholes and caves. Groups of hills rise steeply from the plains 


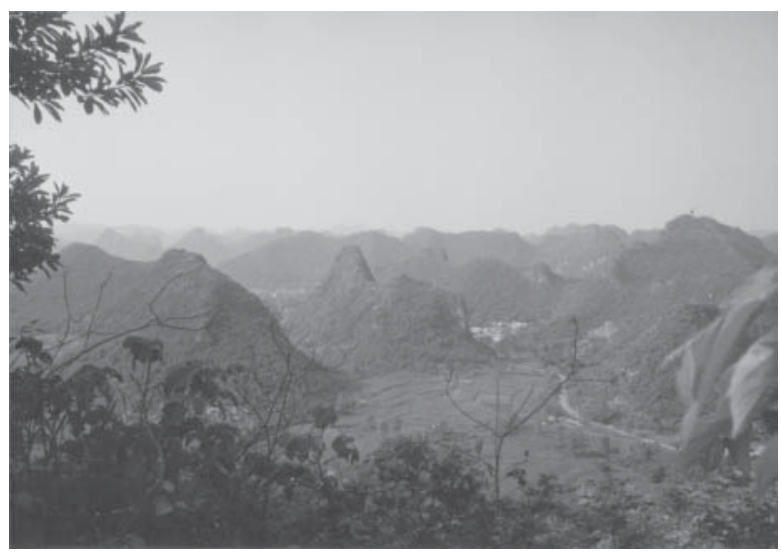

Plate 1 Typical landscape of the area surveyed for François' langur in Fusui Nature Reserve (Fig. 1), with steep, forested limestone hills, villages and cultivated land.

and are separated from each other by farmland, rivers and roads (Plate 1 ). The maximum height of the hills surveyed was $600 \mathrm{~m}$. Steep cliffs make most of the hillsides inaccessible, and so it was necessary to undertake surveys from the base of the hills. It was also possible to use trails to reach central valleys within groups of hills. The vegetation in the Reserve is tropical forest typical of the Sino-Vietnamese plant province and is dominated by Eberhardtia aurata, Hopea chinensis and Saraca chinensis (Wang et al., 1989), although the species composition varies depending on the degree of human impact. Semi-deciduous natural forest now occurs in $<10 \%$ of Guangxi (WWF, 1996) and is found only on the hills, where trees are mostly small in size and covered with lianas. Almost all the flat ground both inside and outside the valleys has been cultivated. The natural habitat has become fragmented and the langurs occur in isolated populations with no connecting corridors of suitable habitat.

\section{Methods}

It is difficult to carry out systematic surveys in this area because of the topography, but all groups of hills within the area were surveyed during three periods totalling 171 days. The survey techniques that we adopted have been used by others to survey for langurs in karst hills (Lu \& Huang, 1993; Hu et al., 1998). Local villagers were employed to work with us to survey all groups of hills (Lu \& Huang, 1993); up to seven staff were in the field each day. In smaller groups of hills with no internal valleys staff divided into two teams, and surveyed each side of the hill from along its base. For larger groups of hills with internal valleys staff divided into three teams, one of which used trails to survey the valleys.

Each team recorded vegetation and degree of cultivation. When langurs were observed, records were made of the time of detection, number of individuals, age and sex classes and duration of observation, and the locality was marked on 1:10,000 maps. The age and sex classes were identified according to fur colour, body size and secondary sexual characteristics. Infants have a distinct golden pelt, while both adults and juveniles have black pelts and are smaller. These features can be observed in the field, although sometimes it was difficult to fully distinguish the age or sex of particular groups. The langurs' wariness made it difficult to identify individuals. When no visual observations were made, we searched for fresh faeces left by langurs.

The reliability of individual counts depended largely on the frequency of repeat surveys. Each hill group was surveyed at least twice during each fieldwork period. Hill groups where langurs or fresh faeces were found were surveyed three times in the first period, twice in the second and six times in the third. Surveys started at 06.00 in summer and 06.30 in winter and finished at c. 19.00 at all times. There was a break in surveys from 11.00 to 15.00 , a time when langurs usually hide in dense bushes or caves (Jiang et al., 1991; Li, 1992; Li, 1994; Huang et al., 2000).

An observation of one langur group was considered to be a record. Any records considered inaccurate, such as where the number of individuals in a group was not precisely recorded, were discarded. Any duplicate sightings were taken as one record. During each fieldwork period, records of the same langur groups at different times were used for comparison or for revising the data. The daily localities of langur sightings were transferred from the 1:10,000 maps to a 1:50,000 map.

Information on hunting was collected from records at the Fusui Reserve Station and from informally interviewing local residents. The records of the dates and places of hunting were compared to see if they referred to the same incident. Interviews with 46 families in 10 villages inside or adjacent to the survey area provided data on family size, area of cultivated land, fuel used and annual gross income. The villages visited and the families interviewed were chosen at random during the field season. We collected the socioeconomic information by interviews because, apart from a population census in 1998, there had been no other socioeconomic study since 1985 .

\section{Results}

There are 15 separate hill groups $\left(c .37 \mathrm{~km}^{2}\right)$ within the survey area $\left(55 \mathrm{~km}^{2}\right)$. Hills within the five larger groups are in many cases connected by ridges, and some central valleys are inaccessible for cultivation. The forest is relatively intact on the larger hills. By comparison, the 10 smaller hill groups are surrounded by cultivated land, where the natural vegetation has been cleared. Almost all 
gentle slopes are cultivated and there is encroachment into the hills and forests.

During the surveys we made a total of 82 observations of langurs, of which five were unclear and 28 were duplicates, giving 49 unique records of groups and individuals. During the first fieldwork period we located 45 individuals (Table 1), of which two were solitary old males (VIII and IX), two were a pair of young males (X), and 41 were living in seven mixed sex groups (I-VII). Three mixed sex groups (I-III) were found in a small hill group where the vegetation was comparatively poor and isolated by large-scale cultivation. The other four mixed sex groups (IV-VII) were distributed among three larger hill groups. The solitary males and the all-male group were close to where the vegetation was comparatively poor. The solitary males and the all-male group were not included in calculation of group size and density but were used to calculate population density (Table 1).

During the second fieldwork period we located only six of the langur groups, totalling 26 individuals (Table $1)$. Two individuals had disappeared: an infant from group I and an adult female from group II. The total number of langurs could have been underestimated during this period due to the fewer number of days of fieldwork.

During the third fieldwork period we recorded only three of the groups, despite this being the longest of the three fieldwork periods: mixed sex groups (II, V and VI), totalling 23 individuals (Table 1). The three groups occurred as isolated populations in two larger and one smaller hill group. During this period we were unable to locate the other seven groups: four mixed sex groups and all solitary males. An interview with a villager suggested that Group III had been hunted in late January 2001 but this could not be confirmed. The number of langurs appeared to have declined by c. $50 \%$ within one year (i.e. between the first and third periods of fieldwork).

The Fusui Reserve Station did not have any records of the hunting of François' langurs, but from 1997 to 2001 poaching was said to have occurred six times, twice in 1997 and 1998, and once in 2000 and 2001 (information from interviews with 14 villagers). We did not observe any hunting of langurs during our fieldwork but we heard shooting within the survey area on three occasions.

There were 19 villages within or adjacent to the survey area, with a total population of $c .2,500$. The interviews with 46 families living within or adjacent to the Reserve showed that $19(41.3 \%)$ had three or more children, 12 (26.1\%) had two, 12 had one, and three (6.5\%) had none. The average family size was four (range $2-7)$. On average each family owned c. 3 ha (c. $40 \mathrm{mu}, 1 \mathrm{mu}=0.068 \mathrm{ha}$ ) of cultivated land, of which 2 ha was for sugarcane and 1 ha for other crops. Forty-one of the families used firewood for cooking and heating, and five used gas. The average family annual gross income was c. US $\$ 2,800$ (c. 23,000 Yuan), of which two thirds (c. US \$1,800) came from sugarcane plantations.

\section{Discussion}

In 1995 there were 86 François' langurs in the northern part of Fusui Reserve, in the area we surveyed (Fusui Reserve Station, unpub. data; Liu \& Wei, 1995). The population density was 2.3 individuals $\mathrm{km}^{-2}$, whereas

Table 1 The number of individuals and group composition ${ }^{1}$ of 10 groups (I-X) of François' langur recorded in the surveyed area of Fusui Nature Reserve (Fig. 1) during three surveys from July 2000 to June 2001.

\begin{tabular}{|c|c|c|c|c|}
\hline Group no. & $\begin{array}{l}\text { First survey } \\
\text { (July-September 2000) }\end{array}$ & $\begin{array}{l}\text { Second survey } \\
\text { (November-December 2000) }\end{array}$ & $\begin{array}{l}\text { Third survey } \\
\text { (March-June 2001) }\end{array}$ & Remark \\
\hline I & 5 (1 AM, 3 AF, 1 I) & 4 (1 AM, $3 \mathrm{AF})$ & & \\
\hline II & 4 & 3 (1 AM, 2 AF) & 4 (1 AM, $3 \mathrm{AF})$ & \\
\hline III & 7 (1 AM, 3 AF, 2 J, 1 I) & $7(1 \mathrm{AM}, 3 \mathrm{AF}, 3 \mathrm{~J})$ & & $\begin{array}{l}\text { Possibly hunted in } \\
\text { Jan. } 2001\end{array}$ \\
\hline IV & $6(1 \mathrm{M}, 2 \mathrm{~F}, 2 \mathrm{~J}, 1 \mathrm{I})$ & $6(1 \mathrm{M}, 2 \mathrm{~F}, 3 \mathrm{~J})$, & & \\
\hline V & $7(5 \mathrm{~A}, 2 \mathrm{~J})$ & & 8 (1 AM, 2 AF, 3 J, 2 I) & \\
\hline VI & $5(4 \mathrm{~A}, 1 \mathrm{~J})$ & 5 & 11 (at least $5 \mathrm{~A}, \mathrm{~J} 2,1 \mathrm{I})^{2}$ & \\
\hline VII & 7 (1 AM, 2 AF, 2 J, 2 I) & & & \\
\hline VIII & $1 \mathrm{AM}$ & & & \\
\hline IX & $1 \mathrm{AM}$ & $1 \mathrm{AM}$ & & \\
\hline$x$ & $2 \mathrm{AM}$ & & & \\
\hline Total & 45 & 26 & 23 & \\
\hline No. survey days & 60 & 21 & 90 & \\
\hline Mean group size & 5.9 & 5.2 & 7.7 & \\
\hline Group density $\left(\mathrm{km}^{-2}\right)$ & 0.2 & 0.14 & 0.1 & \\
\hline Population density $\left(\mathrm{km}^{-2}\right)$ & 1.2 & 0.7 & 0.6 & \\
\hline
\end{tabular}

${ }^{1} \mathrm{AM}$, adult male; AF, adult female; J, juvenile; I, infant; A, adult (when sex could not be recognized).

${ }^{2}$ The other three individuals could not be distinguished due to a short observation time and the density of vegetation. 
in 2000-2001 we recorded mean densities of 0.6-1.2 individuals $\mathrm{km}^{-2}$, i.e. $26-52 \%$ of the 1995 figures. We do not know the survey methods used by the Fusui Reserve Station and Liu \& Wei (1995) and their reports do not contain data on the numbers of langur groups, and thus it is difficult to make comparisons between the two time periods.

In our third survey period, of 90 days, we recorded a population density that was only $50 \%$ of that recorded in our first survey period, which was $c .12$ months earlier and lasted 60 days. The same survey methods were used in both periods, and the same surveyors undertook the work. It seems unlikely that individual langurs emigrated from the area, as it is bordered to the south by the Zuojiang River and elsewhere by a highway and extensive farmland with intensive human activity.

Although we were not able to locate any records of the hunting of François' langurs other than from our interviews with villagers, the Fusui Reserve Station has recorded four cases of hunting of white-headed langurs (Huang et al., 2002). The lack of recorded information on hunting within the area survyed is probably because the Reserve Station is $c .70 \mathrm{~km}$ to the south. The staff appear to rarely visit the northern area due to funding limitations.

Habitat loss and destruction, hunting and the limitations of current conservation management appear to be threatening François' langur. Globally, habitat destruction is a significant factor contributing to the decline of primates (Mittermeier, 1984). Habitat destruction and fragmentation cause reduced population viability in primates (Kirkpatrick, 1996), changes in home ranges (Li et al., 1999) and disruption of normal activities (Huang et al., 2000). Native habitat is seriously threatened in Fusui Reserve because of the increasing demand of residents for cultivated land and firewood. Within the survey area, there are 15 forested hill groups, of which the largest is no more than $10 \mathrm{~km}^{2}$ and the smallest c. $1 \mathrm{~km}^{2}$. According to Huang et al. (2000) white-headed langurs spend two thirds of their feeding and resting time at the foot of hills where most of their food-plant species are found. François' langurs, which use similar habitats, may behave in a similar way and thus encounter problems of food supply, which is the main limiting factor to colobine populations (Davies, 1994).

Habitat destruction in this area was mainly due to the demand for cultivated land and firewood. Birth control legislation appears not to be strictly enforced and the average family size is four, increasing the demand for cultivated land and firewood over and above what would be required for the legislated family size of 3 (parents and one child). Information from interviews showed that most of the local families meet their cooking and heating needs by collection of firewood from the forest.
We make a number of recommendations that would help improve the current conservation status of Francois' langur in Fusui Nature Reserve: (1) the introduction of a methane-generating facility would reduce the need for firewood gathering and consumption; (2) the revision of local government policies, which are in favour of sugarcane plantation, could halt further encroachment into the forest, as would the improved development of the available high-quality agricultural land rather than the continued cultivation of marginal land; (3) the encouragement of the cultivation of more economically valuable crops, such as watermelon, pineapple, litchi, mulberry trees and hemp, could reduce the need to bring more land into cultivation; (4) the provision of increased financial support to the Reserve Station from both Guangxi Forestry Department and the Fusui local government could improve the monitoring and prevention of any hunting.

There are laws for the control of hunting in Fusui Nature Reserve but not for the control of logging or cultivation conducted by local residents, who are the owners of the forest and the land. If this situation cannot be altered, the future for Francois' langur in the Reserve is bleak. The authorities of the Reserve need to be given the ability to protect both the animals and their habitat, and this issue will require the collaboration of both Guangxi Forestry Department and Guangxi Government. The Guangxi Forestry Department now has plans to merge the Fusui and Congzuo Nature Reserves (Fig. 1) and upgrade them to a National Class Nature Reserve, which has laws for the protection of both animals and their habitats.

\section{Acknowledgements}

Our special thanks to Prof. C. Groves (Australian National University), M. Dunn (BP Conservation Programme), K. McConkey and an anonymous reviewer for their patience and insightful comments on the manuscript. We are grateful to K. Gotto, R. Mitchell and P. Mathew (BP Conservation Programme) and Prof. C.M. Huang (Guangxi Normal University) for their patience, valuable help and encouragement, and to L. Liang for drawing the figure. Thanks also go to Dr Z.Y. Li, G.Q. Yao and K. Zhou (Southwest Forestry University), Q.H. Zhou (GNU), H.Q. Huang, X.M. Meng, Q. Lu and S.Y. Lueng (Fusui Nature Reserve) and Z.H. Huang (Congzhuo Nature Reserve) for their help with fieldwork. Funding for the research came from the BP Conservation Programme (Project CHINA 2000).

\section{References}

Bennett, E.L. \& Davies, A.G. (1994) The ecology of Asian colobines. In Colobine Monkeys: Their Ecology, Behaviour, and 
Evolution (eds A.G. Davies \& J.F. Oates), pp. 129-171.

Cambridge University Press, Cambridge, UK.

Davies, A.G. (1994) Colobine populations. In Colobine Monkeys: Their Ecology, Behaviour, and Evolution (eds A.G. Davies \& J.F. Oates), pp. 285-310. Cambridge University Press, Cambridge, UK.

Ding, B., Zhang, Y.P., Liu, Z.M. \& Wei, Y. (1999) Preliminary report on classification status of the white-headed langur inferred from random amplified polymorphism DNA. Zoological Research, 20, 1-6.

Eudey, A.A. (1987) Action Plan for Asian Primate Conservation: 1987-91. IUCN, Gland, Switzerland.

Fooden, J. (1976) Primates obtained in Peninsular Thailand, June-July, 1973, with notes on the distribution of continental Southeast Asian leafmonkeys (Presbytis). Primates, 17, 95-118.

Groves, C.P. (2001) Primate Taxonomy. Smithsonian Institution Press, Washington, DC, USA.

Guangxi Forestry Department (1993) Nature Reserves of Guangxi. China Forestry Press, Beijing, China [in Chinese].

Hu, G., Wei, Y. \& Li, Z.Y. (1998) The survey on the white-headed langur in Longrei and the analysis of the cause for endangerment. Journal of Guangxi Normal University, 16, 71-75 [in Chinese].

Hu, G., Wei, Y. \& Li, Z.Y. (1999) The population density and endangered status of the white-headed langur in Bapen Reserve. Territory \& Natural Resources Study, 81, 63-66 [in Chinese].

Huang, C.M., Ren, F. \& Lu, L.R. (1995) Night-staying cave selecting strategy of white-headed langur. Chinese Journal of Zoology. 30, 36-37 [in Chinese].

Huang, C.M. \& Sun, R.Y. (2001) White-headed langur and its feeding biology. Biological Bulletin, 36, 3-4 [in Chinese].

Huang, C.M., Wei, F.W., Li, M., Quan, G.Q. \& Li, H.H. (2002) Current status and conservation of white-headed langur (Trachypithecus leucocephalus) in China. Biological Conservation, 104, 221-225.

Huang, C.M. \& Xue, Y.G. (1998) Behaviour research on white-headed langur - individual behaviour. Journal of Guangxi Normal University, 16, 91-96 [in Chinese].

Huang, C.M., Xue, Y.G., Wei, Y. \& Li, Y.B. (2000) Habitat vegetation and selection of white-headed leaf monkey (Trachypithecus leucocephalus). Acta Theriologica Sinica, 20, 181-185 [in Chinese].

Huang, J.T., Huang, L.B. \& Guo, Y.R. (1983) Ecology of Francois' langur. Chinese Wildlife, 1, 11-12 [in Chinese].

Jiang, H.S., Fen, M., Wang, J., Wu, M.C., Lai, Y.M. \& Liu, Z.M. (1991) The distribution and ecological habit of white-headed langur (Presbytis leucocephalus). Acta Theriologica Sinica, 11, 236-237 [in Chinese].

Kirkpatrick, R.C. (1996) The natural history and conservation of the snub-nosed monkeys (Genus Rhinopithecus). Biological Conservation, 72, 363-369.

Li, B.G., Ren, B.P. \& Gao, Y.F. (1999) A change in the summer home range of Sichuan snub-nosed monkey in Yuhuangmiao, Qinling Mountains. Folia Primatologica, 70, 269-273.

Li, M.J. (1994) Study on ecology of black leaf monkey in Guizhou Provincial Mayang River Nature Reserve. In Scientific Survey of the Mayang River Black Leaf Monkey Reserve (ed. Guizhou Forestry Department), pp. 33-38. Guizhou National Publishing House, Guizhou, China [in Chinese].

Li, M.J. (1995) Ecological study of the Tonkin langur (Trachypithecus francoisi) in Guizhou, China. In Primate Research and Conservation (eds W.P Xia \& R.Z. Zhang), pp. 226-231. China Forestry Publishing House, Beijing, China [in Chinese].
Li, Z.X. \& Ma, S.L. (1980) A revision of the white-headed langur. Acta Zootaxonomica Sinica, 5, 440-442 [in Chinese].

Li, Z.Y. (1992) Time budgets of Presbytis leucocephalus. Acta Theriologica Sinica, 12, 7-13 [in Chinese].

Li, Z.Y. (1993) Preliminary investigation of the habitat of Presbytis francoisi and Presbytis leucocephalus, with notes on the activity pattern of Presbytis leucocephalus. Folia Primatologica, 60, 83-93.

Liu, W.F. \& Wei, Z.Y. (1995) Present status and protection of primates in Guangxi, China. In Primate Research and Conservation (eds. W.P Xia \& R.Z. Zhang), pp.123-132. China Forestry Publishing House, Beijing, China [in Chinese].

Liu, Z.M., Wei, Y., Ma, X.Z., Wang, W., Chen, Y.J. \& Zhang, Y.P. (1997) Preliminary studies of the classification of Trachypithecus francoisi based on mitochondrial ND4 and D-Loop DNA. Guangxi Sciences, 4, 64-71 [in Chinese].

Lu, L.R. \& Huang, C.M. (1993) Investigation of the population of white-headed langur (Presbytis leucocephalus.). Acta Theriologica Sinica, 13, 11-15 [in Chinese].

Lu, L.R. \& Li, Z.Y. (1991). On the taxonomy of the white-headed langur. Journal of Guangxi Normal University, 9, 67-70 [in Chinese].

Luo, Y., Chen, Z.R. \& Wang, S.X. (2000) Observations of the food habit of Presbytis francoisi in Mayanghe region, Guizhou Province. Chinese Journal of Zoology, 35, 44-49 [in Chinese].

Ma, S.L. \& Wang, Y.X. (1988) The recent distribution, status and conservation of primates in China. Acta Theriologica Sinica, 8(4), 250-260 [in Chinese].

Ma, S.L., Wang, Y.X. \& Poirier, F.E. (1989) Taxonomy and distribution of the Francois' langur (Presbytis francoisi). Primates, 30, 233-240.

Mittermeier, R.A. (1984) Global overview of primate conservation. In Primate Ecology and Conservation (eds J. G. Else \& L.P.C. Lee), pp. 326-340. Cambridge University Press, Cambridge, UK.

Tan, B.J. (1955) Apes in China. Bulletin of Biology, 3, 17-23 [in Chinese].

Wang, H.P., Chen, S.C., \& Wang, S.Y. (1989) China. In Floristic Inventory of Tropical Countries (eds D.G. Campbell \& H.D. Hammond), pp. 35-43. The New York Botanical Garden, New York, USA.

Wang, W., Forstner, M.R.J., Zhang, Y.P., Liu, Z.M., Wei, Y., Huang, H.Q., Hu, H.G., Xie, Y.X. Wu, D.H. \& Melnick, D.J. (1997) A phylogeny of Chinese leaf monkey using mitochondrial ND3-ND4 gene sequences. International Journal of Primatology, 18, 305-319.

Wang, Y.X., Jiang, X.L. \& Feng, Q. (1999) Taxonomy, status and conservation of the leaf monkey in China. Zoological Research, 20, 306-315 [in Chinese].

WWF (1996) Biodiversity details in Guangxi. In A Biodiversity Review of China (ed. G. Carey), pp. 346-367. WWF China Programme, Hong Kong.

Yang, Y.Q. (1994) Investigation on the black leaf monkey in the Mayang River Nature Reserve. In Scientific Survey of the Mayang River Black Leaf Monkey Reserve (ed. Guizhou Forestry Department), pp. 1-14. Guizhou National Publishing House Guizhou, China [in Chinese].

Zhang, R.Z., Quan, G.Q., Zhao, T.G. \& Southwick, C.H. (1992) Distribution of primates (except Macaca) in China. Acta Theriologica Sinica, 12, 81-95.

Zhou, Q.H., Huang, C.M. \& Fang, Y. (2001) Preliminary research on time budget of Francois' langur in summer. Journal of Guangxi Normal University, 19, 80-83 [in Chinese]. 


\section{Biographical sketches}

Gang $\mathrm{Hu}$ studies the ecology and conservation of langurs and other threatened mammals, including red panda and takin. Whilst at Yunnan Wildlife Conservation Association he worked on the establishment of a multimedia information system for wildlife and reserves in Yunnan Province.

Xin Dong has research interests in wildlife conservation management, and has been involved in all phases of the development of the multimedia information system for wildlife and reserves in Yunnan.

Yi Wei has worked since 1992 in Guangxi Forestry Department on primate conservation and reintroduction management.

Ying Zhu has interests in general primatology and is currently involved in the monitoring of wild primates, including gibbon and Phayre's langur, in Gaoligong Nature Reserve.

Xihuan Duan studies human impacts on wildlife and has been involved in the preparation of the Wuliangshan Reserve Conservation Strategy and Action Plan. 